\title{
PERAMALAN HARGA DAN PERMINTAAN KOMODITAS TEMBAKAU DI KABUPATEN JEMBER
}

\author{
Oleh : \\ OKTANITA JAYA ANGGRAENI *)
}

\begin{abstract}
ABSTRAK
Tembakau merupakan komoditas perkebunan yang sangat penting bagi perekonomian Indonesia. Meskipun demikian, komoditi tembakau terutama di Kabupaten Jember menghadapi berbagai permasalahan, diantaranya adalah ketidakpastian harga tembakau dan fluktuasi produksi tembakau.

Tujuan kegiatan penelitian untuk mengetahui metode peramalan yang paling tepat untuk komoditas tepat di Kabupaten Jember. Target penelitian ini adalah dihasilkannya metode yang sesuai dalam peramalan komoditas tembakau kasturi sehingga dapat digunakan petani dalam menata pola tanamnya. Penelitian ini menggunakan data sekunder. Data sekunder diperoleh dari harga dan pemintaan komoditas tembakau di Kabupaten Jember. Data yang diambil selama kurun waktu tahun 2006-2011. Data yang telah dikumpulkan diteliti dan dianalisis dengan menggunakan metode peramalan Moving Average, Exponential Smoothing, Regresi Linier (Trend).

Berdasarkan hasil perhitungan pada penilitian ini, menunjukkan bahwa metode peramalan Eksponensial Smoothing merupakan metode yang paling tepat dalam memberikan nilai ramalan untuk harga dan permintaan tembakau kasturi. Hal ini terlihat dari hasil nilai MSE terkecil, yaitu sebesar 3.349.763 untuk harga tembakau kasturi. Sedangkan nilai MSE terkecil untuk permintaan tembakau, yaitu sebesar 110.305. Dengan menggunakan metode yang tepat diharapkan akan menghasilkan nilai ramalan mendekati nilai aktualnya.

Peramalan harga tembakau kasturi di Kabupaten Jember yang dilakukan dengan metode eksponensial smoothing dalam 10 tahun ke depan menghasilkan harga tembakau kasturi yang cenderung meningkat tetapi tidak dalam persentase yang besar. Dengan kenaikan sebesar Rp 40,sampai Rp 80,- per periode. Harga tembakau kasturi pada tahun 2012 atau periode peramalan pertama adalah sebesar Rp 38.739,-. Sedangkan harga tembakau kasturi tertinggi pada tahun 2021 adalah sebesar Rp39.289,-. Untuk permintaan tembakau, hasil peramalan yang dihasilkan menunjukkan tingkat permintaan tembakau kasturi yang berfluktuasi setiap periodenya. Permintaan tertinggi selama 10 periode mendatang terjadi pada tahun 2013 dengan permintaan sebesar 11.688 Ton, dengan ratarata fluktuasi kenaikan atau penurunan sebesar 10 sampai 1.200 Ton setiap tahun.
\end{abstract}

Kata Kunci : Metode Peramalan, Komoditas Tembakau Kasturi 


\section{Pendahuluan}

Petani sebagai tonggak sektor pertanian sering menemui permasalahan risiko dan ketidakpastian di dalam dunia pertanian sehingga hal tersebut perlu diperhitungkan. Ada dua risiko utama yang menjadi perhatian risiko sektorharga pertanian disebabkan oleh volatilitas potensial di harga dan risiko produksi yang dihasilkan dari ketidakpastian tentang tingkat produksi yang produsen primer dapat dicapai dari kegiatan mereka saat ini.

Tembakau merupakan komoditas perkebunan yang sangat penting bagi perekonomian Indonesia. Meskipun demikian, komoditi tembakau terutama di Kabupaten Jember menghadapi berbagai permasalahan, diantaranya adalah ketidakpastian harga tembakau dan fluktuasi produksi tembakau. Risiko sering terjadi di luar batas toleransi (kontrol petani) petani dan pada hakikatnya sulit untuk diukur. Namun, fenomena lapang ini pada hakikatnya menarik untuk diteliti guna dapat memprediksi efisiensi pola tanam lahan sebagai akibat dari faktor ketidakpastian pada kegiatan usahatani.

Fluktuasi produksi tembakau dan ketidakpastian harga tembakau ini memerlukan tindakan pemerintah untuk mengendalikannya, agar tidak memberikan imbas buruk bagi sub sektor perkebunan. Sampai saat ini Dirjen Bina Produksi dan Perkebunan belum memiliki model peramalan yang tepat untuk memperkirakan produksi dan harga tembakau di masa mendatang. Ketidakmampuan pemerintah dalam mempertahankan harga pasar ini akan menyebabkan ketidakstabilan pasar tembakau di masa yang akan datang.

Disisi lain, permintaan akan tembakau secara nasional di perkirakan akan terus meningkat seiring dengan peningkatan jumlah penduduk dan pertumbuhan konsumsi tembakau. Selain itu harga tembakau di pasaran dunia lebih murah dari pada harga di pasar domestik, jika hal ini tidak diimbangi dengan peningkatan produksi yang memadai maka ada kekhawatiran besar atas impor tembakau yang tinggi. Informasi harga tembakau dalam negeri yang lengkap dan akurat sangat dibutuhkan dalam menunjang pengembangan tembakau sebagai komoditi perkebunan unggulan yang sering mengalami ketidakpastian harga pasar.

Salah satu cara untuk mengetahui kemampuan Kabupaten Jember dalam permintaan tembakau dan tingkat harga adalah dengan melakukan peramalan untuk beberapa tahun yang akan datang. Peramalan dibutuhkan sebagai informasi dasar untuk menyusun perencanaan dan pengambilan keputusan di masa mendatang. Peramalan merupakan alat bantu yang penting dalam perencanaan yang efektif dan efisien. Dengan demikian dapat disimpulkan bahwa peramalan merupakan dugaan mengenai suatu kejadian pada waktu yang akan datang yang dapat digunakan untuk melakukan perencanaan dan pengambilan keputusan.

\section{Perumusan Masalah}

Permasalahan yang akan dibahas dala penelitian ini adalah sebagai berikut:

1. Bagaimanakah metode peramalan dengan menggunakan metode moving average, exponential smoothing dan regresi (trend)?

2. Bagaimanakah menentukan metode peramalan yang tepat untuk komoditas tembakau kasturi di Kabupaten Jember?

\section{Batasan Masalah}

Permasalahan yang akan dibahas dalam penelitian ini dibatasi pada hal-hal sebagai berikut :

1. Penelitian ini menggunakan komoditas tembakau jenis kasturi yang banyak dibudidayakan di Kabupaten Jember.

2. Penelitian ini dilakukan di Kabupaten Jember dengan menggunakan data permintaan dan harga dari Dinas Perkebunan dan Kehutanan serta UPT Sertifikasi Mutu Barang dan Lembaga Tembakau Jember.

Asumsi yang digunakan dalam penelitian ini adalah bahwa data yang diperoleh tidak terdapat perubahan yang cukup signifikan selama proses pengolahan data.

\section{Tujuan}

Secara umum tujuan penelitian ini adalah mendapatkan informasi terkait penentuan metode peramalan yang tepat untuk komoditas tembakau di Kabupaten Jember.

Secara khusus penelitian ini bertujuan :

1. Untuk mengetahui peramalan menggunakan metode moving average, exponential smoothing dan regresi (trend).

2. Untuk menentukan metode peramalan yang tepat untuk komoditas tembakau di Kabupaten Jember. 


\section{Manfaat}

Hasil penelitian ini diharapkan dapat memberikan sumbangan bagi pengembangan ilmu dan kegunaan praktis sebagai berikut :

1. Dapat memberikan sumbangan berupa penentuan metode peramalan yang tepat untuk komoditi tembakau sehingga dapat digunakan bagi petani dalam menentukan pola tanam lahannya.

2. Dapat memberikan sumbangan berupa bahan informasi bagi pihak-pihak yang tertarik pada kepentingan dalam pembangunan daerah Kabupaten Jember, khususnya pembangunan pertanian.

3. Dapat dipergunakan sebagai masukan informasi awal sebelum melaksanakan penelitian di bidang yang sama bagi calon peneliti.

4. Dapat memberikan informasi penentuan metode peramalan yang tepat untuk komoditi tembakau sehingga dapat digunakan bagi petani dalam menentukan pola tanam lahannya di masing-masing wilayah serta sebagai bahan pertimbangan bagi pemerintah daerah Kabupaten Jember untuk mengembangkan sektor peranian serta menjadikannya salah satu produk unggulan Kabupaten Jember.

\section{Metode Penelitian}

Penelitian ini menggunakan metode analisis data dengan menggunakan pendekatan deskriptif dan analitis. Menurut Masri Singarimbun dan Sofian Effendi (1989), penelitian deskriptif dimaksudkan untuk melakukan pengukuran terhadap fenomena sosial tertentu. Penelitian deskriptif adalah mendeskripsikan permasalahan yang ada dan menganalisis sehingga dapat ditarik kesimpulan.

Penentuan lokasi penelitian dilakukan secara sengaja, yaitu di Kabupaten Jember yang terletak di Propinsi Jawa Timur, dengan pertimbangan daerah ini mempunyai potensi yang besar dalam sektor pertanian baik dalam sektor pemanfaatannya maupun untuk dikembangkan sehingga memberikan kontribusi yang tinggi terhadap peningkatan pertumbuhan ekonomi daerah. Jangka waktu penelitian adalah 4 bulan.

Dalam pengumpulan data penelitian terdapat dua tahapan yang dilakukan yaitu sebagai berikut :

a) Tahapan pengumpulan data sekunder yang diperoleh dari Dinas Perkebunan dan Kehutanan Kabupaten Jember, UPT Sertifikasi Mutu Barang dan Lembaga Tembakau Dinas Perindustrian Propinsi
Jawa Timur, baik melalui kompilasi data statistik permintaan dan harga tembakau kasturi tahun 2006 hingga 2011. Selain itu informasi dan data sekunder diperoleh dari pustaka dan literatur, baik yang dipublikasikan maupun yang tidak dipublikasikan.

b) Tahap pengumpulan data primer dengan menggunakan daftar pertanyaan terkait tembakau kasturi melalui metode wawancara. Individu sasaran yang diwawancara adalah petani, karyawan instansi yang membidangi tembakau dan pengusaha importir tembakau.

Data yang telah dikumpulkan diteliti dan dianalisis dengan menggunakan alat analisis sebagai berikut:

\section{Metode Analisis Moving Average}

Moving average (MA) diperoleh dengan merata-rata permintaan berdasarkan beberapa data masa lalu yang terbaru. Tujuan utama dari penggunaan teknik peramalan ini adalah untuk mengurangi aatau menghilangkan variasi acak permintaan dalam hubungannya dengan waktu. Tujuan ini dicapai dengan merata-ratakan beberapa nilai data secara bersama-sama, dan menggunakan nilai rata-rata tersebut sebagai ramalan permintaan untuk periode yang akan datang. Disebut rata-rata bergerak karena begitu setiap data aktual permintaan baru deret waktu tersedia maka data aktual permintaan yang paling terdahulu akan dikeluarkan dari perhitungan kemudian suatu nilai rata-rata baru akan dihitung.

Secara matematis, maka moving average (MA) akan dinyatakan dalam persamaan sebagai berikut:

$$
M A=\frac{A+A_{-}+\ldots .+A_{-1-1}}{N}
$$

Dimana :

$A_{t}=$ Permintaan aktual pada periode ke-t $\mathrm{N}=$ jumlah data permintaan yang dilibatkan dalam perhitungan MA

Karena data aktual yang dipakai untuk perhitungan MA berikutnya selalu dihitung dengan mengeluarkan data yang paling terdahulu, maka:

$$
M A_{t}=M A_{t-1}+\frac{A_{t}-A_{t-N}}{N}
$$




\section{Analisis Smoothing}

Smoothing juga dikenal sebagai simple Exponential Smoothing atau metode Exponential Smoothing sederhana. Simple Smoothing digunakan untuk peramalan dengan jangka waktu pendek, biasanya hanya satu bulan ke depan. Model ini mengasumsikan bahwa data berfluktuasi di sekitar rata - rata yang stabil (tidak ada trend atau pertumbuhan pattern yang konsisten). Rumus dari model Single Exponential Smoothing adalah sebagai berikut :

$$
F_{i+1}=a D_{i}+(1-a) F_{i} \ldots
$$

\section{Analisis Regresi Linier}

Penggunaan metode ini didasarkan kepada variabel yang ada dan yang akan mempengaruhi hasil peramalan. Hal- hal yang perlu diketahu sebelum melakukan peramalan dengan metode regresi adalah mengetahui terlebih dahulu mengetahui kondisi- kondisi seperti :

a. Adanya informasi masa lalu

b. Informasi yang ada dapat dibuatkan dalam bentuk data (dikuantifikasikan)

c. Diasumsikan bahwa pola data yang ada dari data masa lalu akan berkelanjutan dimasa yang akan datang. adalah :

Adapun data- data yang ada dilapangan

a. Musiman (Seasonal)

b. Horizontal (Stationary)

c. Siklus (Cylikal)

d. Trend

Ada dua pendekatan untuk melakukan peramalan dengan menggunakan analisis deret waktu dengan metode regresi sederhana yaitu :

1. Analisis deret waktu untuk regresi sederhana linier

2. Analisis deret untuk regresi sederhana yang non linier

Untuk menjelaskan hubungan kedua metode ini kita gunakan notasi matematis seperti

$$
Y=F(x)
$$

Dimana :

$\mathrm{Y}=$ Dependent variable (variabel yang dicari)

$\mathrm{X}=$ Independent variable (variabel yang mempengaruhinya)

Notasi regresi sederhana dengan menggunakan regresi linier (garis lurus) dapat digunakan sebagai berikut :

$$
\boldsymbol{Y}=\boldsymbol{a}+\boldsymbol{b} \boldsymbol{x}
$$

Dimana a dan b adalah merupakan parameter yang harus dicari. Untuk mencari nilai a dapat digunakan dengan menggunakan rumus :

$$
\mathbf{a}=\bar{Y}-b \bar{x}
$$

kemudian nilai $\mathrm{b}$ dapat dicari dengan rumus :

$$
\mathrm{b}=\frac{\sum X Y-\bar{X} Y}{\sum X^{2}-X \bar{\sum} X}
$$

Beberapa metode lebih ditentukan untuk meringkas kesalahan (error) yang dihasilkan oleh fakta (keterangan) pada teknik peramalan. Sebagian besar dari pengukuran ini melibatkan rata-rata beberapa fungsi dari perbedaan antara nilai aktual dan nilai peramalannya. Perbedaan antara nilai observasi dan nilai ramalan ini sering dimaksud sebagai residual. Persamaan di bawah ini digunakan untuk menghitung error atau sisa untuk tiap periode peramalan.

Dimana :

$$
e_{t}=Y_{t}-\hat{\mathrm{Y}}_{\mathrm{t}}
$$

$e_{t}$ : error ramalan pada periode waktu $t$.

$Y_{t}$ : nilai aktual pada periode waktu $t$.

$\hat{\mathrm{Y}}_{\mathrm{t}}$ : nilai ramalan untuk periode waktu $\mathrm{t}$. The Mean Squared Error (MSE) adalah metode lain untuk mengevaluasi metode peramalan. Masing-masing kesalahan atau sisa dikuadratkan. Kemudian dijumlahkan dan dibagi dengan jumlah observasi. Pendekatan ini mengatur kesalahan peramalan yang besar karena kesalahan-kesalahan itu dikuadratkan. Suatu teknik yang menghasilkan kesalahan moderat mungkin lebih baik untuk salah satu yang memiliki kesalahan kecil tapi kadang-kadang menghasilkan sesuatu yang sangat besar. Berikut ini rumus untuk menghitung MSE :

$$
M S E=\frac{1}{n} \sum_{t=1}^{n}\left(Y_{t}-\hat{Y}_{t}\right)^{2}
$$

\section{Hasil dan Pembahasan}

Fluktuasi yang terjadi pada permintaan dan harga tembakau kasturi di Kabupaten Jember dapat mempengaruhi petani tembakau dalam melakukan produksi tembakau. Prediksi permintaan dan harga tembakau kasturi dapat membantu petani dalam menentukan produksi tembakaunya untuk meminimalkan kerugian yang mereka hadapi. 


\section{Peramalan Dengan Metode Regresi Linier}

Metode Regresi Linier menggambarkan kecenderungan peningkatan dan penurunan dalam jangka panjang dari sekumpulan data harga dan permintaan tembakau kasturi yang dianalisis. Penelitian ini menggunakan metode regresi linier sederhana. Analisis regresi linier untuk peramalan harga tembakau kasturi yang menghasilkan nilai MSE 3.609.980 dengan fungsi $\mathrm{Yt}=25.602+3.629 \mathrm{X}$. Sedangkan analisis

\begin{tabular}{|c|l|c|r|}
\hline No & $\begin{array}{l}\text { Metode } \\
\text { Peramalan }\end{array}$ & $\begin{array}{l}\text { MSE } \\
\text { (Peramalan } \\
\text { Harga) }\end{array}$ & $\begin{array}{l}\text { MSE } \\
\text { (Peramalan } \\
\text { Permintaan) }\end{array}$ \\
\hline 1. & $\begin{array}{l}\text { Regresi Linier } \\
\text { Sederhana }\end{array}$ & 3.609 .980 & 10.043 .868 \\
\hline 2. & $\begin{array}{l}\text { Moving } \\
\text { Average }\end{array}$ & 55.092 .712 & 6.754 .631 \\
\hline 3. & $\begin{array}{l}\text { Eksponensial } \\
\text { Smoothing }\end{array}$ & 3.349 .763 & 110.305 \\
\hline
\end{tabular}

regresi linier untuk peramalan permintaan tembakau kasturi menghasilkan nilai MSE 10.043.868 dengan fungsi $\mathrm{Yt}=11.249+385 \mathrm{X}$.

\section{Peramalan Dengan Metode Moving Average}

Metode Moving average (MA) menggambarkan kecenderungan nilai peramalan dengan merata-rata harga dan permintaan tembakau kasturi berdasarkan beberapa data masa lalu yang terbaru. Maksud dari rata-rata bergerak karena ketika setiap data aktual harga dan permintaan baru deret waktu tersedia maka data aktual harga dan permintaan yang paling terdahulu akan dikeluarkan dari perhitungan kemudian suatu nilai rata-rata baru akan dihitung. Penelitian ini menggunakan metode moving average sederhana. Analisis moving average untuk peramalan harga tembakau kasturi yang menghasilkan nilai MSE terkecil 55.092.712 dengan rata-rata bergerak dua periode. Sedangkan analisis moving average untuk peramalan permintaan tembakau kasturi yang menghasilkan nilai MSE terkecil 6.754.631 dengan rata-rata bergerak tiga periode.

\section{Peramalan Dengan Metode Eksponensial Smoothing}

Metode Eksponensial Smoothing menggambarkan kecenderungan nilai peramalan berdasarkan pengalaman yang lebih kini, yaitu melalui penghalusan dengan merata-rata nilai dari serentetan data yang lalu dengan cara mengurangi secara eksponensial. Hal itu dilakukan dengan memberikan bobot tertentu pada tiap data yang dilambangkan dengan $\alpha$ (alpha) dan bergerak antara 0 sampai 1. Penelitian ini menggunakan metode eksponensial smoothing tunggal. Analisis eksponensial smoothing untuk peramalan harga tembakau kasturiyang menghasilkan nilai MSE terkecil 3.349.763 dengan $\alpha=0,9$. Sedangkan analisis eksponensial smoothing untuk peramalan permintaan tembakau kasturi yang menghasilkan nilai MSE terkecil 110.305 dengan $\alpha=0,9$.

\section{Pemilihan Metode Peramalan Yang Tepat}

Setelah dilakukan penerapan dari beberapa metode peramalan, kemudian dibandingkan secara keseluruhan nilai MSE yang dihasilkan. Perbandingan ini bertujuan untuk mendapatkan metode peramalan yang tepat. Pemilihan metode peramalan yang tepat didasarkan pada nilai MSE terkecil. Nilai MSE setiap metode peramalan harga dan permintaan tembakau kasturi dapat dilihat pada tabel berikut.

\section{Nilai MSE Metode Peramalan Harga dan Permintaan Tembakau Kasturi}

Berdasarkan hasil perhitungan diatas, menunjukkan bahwa metode peramalan eksponensial smoothing merupakan metode paling tepat dalam memberikan nilai ramalan untuk harga dan permintaan tembakau kasturi. Hal ini terlihat dari hasil nilai MSE yang paling rendah, yaitu sebesar 3.349.763 untuk harga tembakau kasturi. Sedangkan hasil nilai MSE yang paling rendah untuk permintaan tembakau, yaitu sebesar 110.305. Dengan menggunakan teknik yang tepat diharapkan akan menghasilkan nilai ramalan mendekati nilai aktualnya.

Peramalan harga tembakau kasturi di Kabupaten Jember yang dilakukan dengan metode eksponensial smoothing dalam 10 tahun ke depan menghasilkan ramalan harga yang cenderung meningkat tetapi tidak dalam persentase yang besar. Dengan kenaikan sebesar Rp 40,- sampai Rp 80,- per periode. Harga tembakau kasturi pada tahun 2012 atau periode peramalan pertama adalah sebesar Rp 38.739,-. Sedangkan harga tembakau kasturi tertinggi pada tahun 2021 adalah sebesar Rp39.289,-. Hasil ramalan harga tembakau dapat dilihat pada Tabel 5.2 . 
Hasil Peramalan Harga Tembakau Kasturi, 2012-2021

\begin{tabular}{|c|c|}
\hline $\begin{array}{c}\text { Periode } \\
\text { (Tahun) }\end{array}$ & $\begin{array}{c}\text { Hasil Peramalan } \\
\text { (Rp) }\end{array}$ \\
\hline 2012 & 38.739 \\
2013 & 38.829 \\
2014 & 38.909 \\
2015 & 38.982 \\
2016 & 39.047 \\
2017 & 39.106 \\
2018 & 39.159 \\
2019 & 39.207 \\
2020 & 39.250 \\
2021 & 39.289 \\
\hline
\end{tabular}

Peningkatan hasil peramalan harga tembakau kasturi yang tidak begitu besar setiap tahunnya ini diduga disebabkan oleh pengelolaan hasil komoditi tembakau di Kabupaten Jember masih belum intensif. Hal ini tercermin dari hasil tembakau rakyat yang masih rendah kualitas dan kuantitas karena sistem pengolahan berupa pengopenan dan pengeringan yang sederhana dan seadanya. Hasil akhir yang kurang intensif ini mengakibatkan harga tembakau hanya meningkat dengan rata-rata rendah. Sedangkan faktor ekonomi lain yang diduga mempengaruhi peningkatan harga tembakau kasturi ini antara lain adalah nilai tukar rupiah/dollar Amerika, dimana nilai tukar ini cenderung bergerak naik setiap waktu, hal ini menyebabkan harga tembakau kasturi yang dalam lintas perdagangannya melibatkan ekspor dan impor secara langsung akan ikut terpengaruh. Selain itu adanya adanya kenaikan harga pupuk dan sarana pendukung lainnya.

Sedangkan untuk permintaan tembakau, hasil peramalan yang dihasilkan Metode Eksponensial Smoothing menunjukkan tingkat permintaan tembakau kasturi yang berfluktuasi setiap periodenya. Permintaan tertinggi selama 10 periode mendatang terjadi pada tahun 2013 dengan permintaan sebesar 11.688 Ton, dengan rata-rata fluktuasi kenaikan atau penurunan sebesar 10 sampai 1.200 Ton setiap tahun.
Hasil Peramalan Permintaan Tembakau Kasturi, 2012-2021

\begin{tabular}{|c|c|}
\hline $\begin{array}{c}\text { Periode } \\
\text { (Tahun) }\end{array}$ & $\begin{array}{c}\text { Hasil Peramalan } \\
\text { (Ton) }\end{array}$ \\
\hline 2012 & 10.786 \\
2013 & 11.989 \\
2014 & 11.387 \\
2015 & 11.688 \\
2016 & 11.538 \\
2017 & 11.613 \\
2018 & 11.575 \\
2019 & 11.594 \\
2020 & 11.585 \\
2021 & 11.589 \\
\hline
\end{tabular}

Rata-rata kenaikan dan penurunan permintaan tembakau diduga disebabkan tembakau bukan merupakan tanaman tahunan dan kualitas hasil panen yang kurang baik. Tembakau dalam masa tanamnya dikenal dengan pola bero, yaitu berselang antara palawija-paditembakau, padi-tembakau-palawija dan padipalawija-tembakau. Setiap periode musiman habis, lahan pertanian akan digunakan sebagai areal komoditi lain. Tembakau yang rentan terhadap gagal panen tiap tahunnya ini, menyebabkan sebagian besar petani tembakau pindah ke komoditi pertanian lain yang lebih menguntungkan. Selain itu adanya pencabutan program subsidi pupuk dan bibit, yang merupakan input utama dalam faktor produksi tembakau pada tahun 1998. Hal ini menyebabkan produksi tembakau mengalami fluktuasi yang cukup signifikan sehingga permintaan tembakau dari pabrikan mengalami fluktuasi.

Metode peramalan yang dapat meminimalisasi MSE sangat relevan untuk melakukan peramalan harga dan permintaan tembakau kasturi dalam beberapa periode ke depan. Informasi harga dan permintaan tembakau kasturi mendatang ini dapat dimanfaatkan oleh bidang pemasaran dalam membuat perencanaan pola produksi

\section{Kesimpulan dan Saran}

Berdasarkan dari penelitian yang telah dilakukan maka kesimpulan yang diperoleh adalah sebagai berikut :

1. Berdasarkan hasil perhitungan pada penilitian ini, menunjukkan bahwa metode peramalan Eksponensial Smoothing merupakan metode yang paling tepat dalam memberikan nilai ramalan untuk harga dan permintaan tembakau kasturi. Hal ini terlihat dari hasil nilai MSE terkecil, yaitu sebesar 3.349.763 untuk harga tembakau 
kasturi. Sedangkan nilai MSE terkecil untuk permintaan tembakau, yaitu sebesar 110.305. Dengan menggunakan metode yang tepat diharapkan akan menghasilkan nilai ramalan mendekati nilai aktualnya.

2. Peramalan harga tembakau kasturi di Kabupaten Jember yang dilakukan dengan metode eksponensial smoothing dalam 10 tahun ke depan menghasilkan harga tembakau kasturi yang cenderung meningkat tetapi tidak dalam persentase yang besar. Dengan kenaikan sebesar Rp 40,- sampai Rp 80,- per periode. Harga tembakau kasturi pada tahun 2012 atau periode peramalan pertama adalah sebesar Rp 38.739,-. Sedangkan harga tembakau kasturi tertinggi pada tahun 2021 adalah sebesar Rp39.289,-.

3. Untuk permintaan tembakau, hasil peramalan yang dihasilkan menunjukkan tingkat permintaan tembakau kasturi yang berfluktuasi setiap periodenya. Permintaan tertinggi selama 10 periode mendatang terjadi pada tahun 2013 dengan permintaan sebesar 11.688 Ton, dengan rata-rata fluktuasi kenaikan atau penurunan sebesar 10 sampai 1.200 Ton setiap tahun.

Berdasarkan hasil peramalan harga dan permintaan tembakau kasturi dapat diberikan beberapa saran sebagai berikut :

1. Peningkatan kualitas tembakau lokal. Hal ini dapat dicapai melalui peningkatan tingkat produktivitas, yang sangat terkait dengan adopsi teknologi baik teknologi pembibitan, budidaya, panen dan pasca panen, peningkatan efisiensi pada industri pengolahan melalui perbaikan manajemen standarisasi mutu dan kualitas hasil melalui sistem pengopenan dan perajangan yang lebih modern.

2. Peningkatan kegiatan research and development pada sektor perkebunan khususnya komoditi tembakau.

Hal ini ditujukan untuk meningkatkan inovasi dan efisiensi produksi dalam menghasilkan jenis-jenis tembakau yang berkualitas demi memenuhi kebutuhan pasar. Peningkatan kualitas tembakau sangat menguntungkan para petani, harganya menjadi lebih tinggi sehingga standar hidup para petani akan meningkat. Selain itu perlu adanya kontinuitas pengelolaan rantai pemasaran dan distibusi tembakau sampai tangan konsumen.

3. Adanya pola kemitraan antara pemerintah, petani dan pabrikan.

Dalam rangka meningkatkan produktifitas pertanian dan mengantisipasi adanya fluktuasi harga perlu adanya pola kemitraan antara pihak pemerintah, petani dan pabrikan. Pola kemitraan ini diharapkan dapat mendekatkan keterkaitan petani dengan pemerintah sebagai pihak penjamin pemasaran, penyedia sarana produksi dan sebagai pembina dalam pengelolaan hasil panen bagi petani. Sedangkan kemitraan dengan pabrikan, diharapkan dapat memberikan kepastian harga dan penerimaan produksi tembakau kasturi dari petani sehingga saling menguntungkan satu dengan yang lain.

\section{Daftar Pustaka}

BPS. 2010. Kabupaten Jember dalam Angka.

BPS. Jember

BPS. 2011. Kabupaten Jember dalam Angka.

BPS. Jember

Gujarati, Damodar dan Sumarno Zain. 2008. Ekonometrika Dasar. Jakarta: Erlangga

Hastuti, E. H. 2008. Pengaruh Penerapan Sistem Agribisnis Terhadap Peningkatan Pendapatan Petani Sayuran di Kabupaten Boyolali. http://eprints.undip.ac.id/19462/1/endan g.pdf. Diakses pada 5 Januari 2012

Purwono, Ir, MS dan Purnama, H, Ir, MSc. Agr. 2007. Budidaya 8 Jenis Tanaman Pangan Unggul. Penebar Swadaya. Jakarta

Litbang. 2008. Analisis Manajemen. www.litbangkabtsm.org. Diakses pada tanggal 5 Januari 2012

Sari, Dwi Mega. 2008. Peramalan Harga Dan Produksi Tembakau Di Indonesia. Skripsi. Institut Pertanian Bogor. Bogor http://repository.ipb.ac.id/bitstream/han dle/123456789/18998/Sari. Dwi Mega_H2008.pdf?sequence=3

Mubyarto. 1995. Pengantar Ekonomi Pertanian Edisi Keempat. Jakarta. LP3ES 
Soetriono, Ir, MP. 2003. Pengantar Ilmu Pertanian. Bayu Media Publishing. Jember

Widjayanti, N.F, SP. 2011. Perwilayahan Komoditas Sub Sektor Pertanian dalam Pengembangan Wilayah Jalur Lintas Selatan (JLS) Kabupaten Jember. Tesis.

Universitas Jember. Jember 